\title{
The Raji Cell Radioimmune Assay for Detecting Immune Complexes in Human Sera
}

\author{
Argyrios N. Theofilopoulos, Curtis B. Wilson, and Frank J. Dixon \\ From the Department of Immunopathology, Scripps Clinic and Research \\ Foundation, La Jolla, California 92037
}

\begin{abstract}
A B S T R A C T A sensitive and simple procedure for the detection and quantitation of soluble complement (C)fixing immune complexes in sera of patients with various disease states has been developed by utilizing $\mathrm{C}$ receptors on Raji cells. These cells lack membrane-bound immunoglobulin but have receptors for IgG Fc, C3b, C3d, and possibly other $\mathrm{C}$ proteins. Uptake experiments showed that both aggregated human gamma globulin (AHG) and 7S IgG bound to receptors for IgG Fc; however, AHG reacted with $C$ bound to cells only via receptors for $\mathrm{C}$ and this binding was much more efficient than via IgG Fc receptors. AHG was used as an in vitro model of human immune complexes and its uptake by Raji cells was quantitated by ${ }^{125} \mathrm{I}$-radiolabeled antihuman IgG. The limit of sensitivity of this test was $6 \mu \mathrm{g} \mathrm{AHG/}$ $\mathrm{ml}$ serum. The ability of Raji cells to detect AHG in serum depended on the amount of radioactive antibody used and the size of aggregates. The presence of an excess of $\mathrm{C}$ somewhat inhibited binding of AHG containing $C$ to Raji cells.
\end{abstract}

The efficient binding of AHG by receptors for $\mathrm{C}$ on Raji cells was used for the detection and quantitation of immune complexes in human sera. Raji cells were incubated with sera to be tested and then reacted with excess radiolabeled antihuman IgG; the amount of radioactivity bound to the washed cells was determined and referred to a standard curve of radioactive antibody uptake by cells previously incubated with increasing amounts of AHG in serum. Thereby immune complexes were detected and quantitated in serum hepatitis, systemic lupus erythematosus, vasculitis, subacute sclerosing panencephalitis, dengue hemorrhagic fever, and malignancies.

\section{INTRODUCTION}

Immune complexes appear to be one of the most important mechanisms by which immunologic tissue injury is

Received for publication 5 June 1975 and in revised form 5 September 1975. produced. Their phlogogenic and immunopathogenic roles have been well established in experimental animal models. The experiments with serum sickness are the most clear-cut examples (1). With the refinement of the necessary techniques, pathogenic immune complexes are increasingly recognized as the cause of many disorders in animals and humans (2). Exogenous as well as endogenous antigens can trigger pathogenic immune responses resulting in deposition of immune complexes in tissues (3). The glomerular filter, arterial wall, and choroid plexus are the sites where immune complexes most commonly deposit (4).

With immunofluorescence and electron microscopy, immune complexes are seen fixed in tissues $(3,5)$. In addition, antibodies can be eluted from the diseased tissues (6). More recently, it has become possible to detect immune complexes directly in the circulation with a variety of new procedures. Such methods include precipitation with $\mathrm{Clq}$ in agarose gels (7), precipitation with monoclonal rheumatoid factor (8), precipitation with polyethylene glycol (PEG) ${ }^{1}(9)$ and its modification-selective precipitation by $\mathrm{PEG}$ of ${ }^{105} \mathrm{I}-\mathrm{Clq}$ bound to complexes-(10), agglutination of latex particles (11), competitive inhibition of uptake of radioactive complexes by guinea pig peritoneal macrophages (12), microcomplement consumption (13), inhibition of antibody-mediated cytotoxicity (14), platelet aggregation (15), cryoprecipitation (16), alternate appearance in the circulation of antigen or antibody $(17,18)$, and analytical ultracentrifugation (19).

1 Abbreviations used in this paper: AHG, aggregated human IgG; BSA, bovine serum albumin; C, complement; DHF, dengue hemorrhagic fever; FITC, fluorescein isothiocyanate; $\mathrm{HB}_{\mathrm{s}} \mathrm{Ag}$, hepatitis $\mathrm{B}$ surface antigen; HSA, human serum albumin; MBIg, membrane-bound immunoglobulin; MEM, minimal essential medium; MEM-HSA, minimal essential medium containing $1 \%$ human serum albumin; NHS, normal human serum; PBS, phosphate-buffered saline; PEG, polyethylene glycol; SGOT, serum glutamic oxaloacetic acid transaminase; SLE, systemic lupus erythematosus; SSPE, subacute sclerosing panencephalitis. 
Raji cells, a human lymphoblastoid cell line with B cell characteristics, may be used as in vitro detectors of circulating immune complexes. These cells lack membrane-bound immunoglobulin ( $\mathrm{MBIg}$ ), but have receptors for IgG Fc, C3b, C3d (20), and C1q (21). Recently, we developed an immunofluorescence test in which complement (C)-fixing immune complexes in sera were detected by the use of $C$ receptors on Raji cells (22). However, this test had the disadvantages of not being quantitative and of requiring blockage of the IgG Fc receptors before use with human sera, to avoid a positive background reaction due to the binding of $7 \mathrm{~S} \mathrm{IgG.} \mathrm{We} \mathrm{now} \mathrm{report} \mathrm{a} \mathrm{modification} \mathrm{of} \mathrm{this} \mathrm{method}$ in which immune complexes in human sera have been demonstrated and quantitated by measuring uptake of radioactive antibody by $\mathrm{IgG}$ in the immune complexes bound to cells.

\section{METHODS}

Lymphoblastoid cell line. Raji cells, which are derived from Burkitt's lymphoma (23), were cultured in Eagle's minimal essential medium (MEM), as has been described (22). Cell viability was determined by trypan blue exclusion. Preliminary experiments have shown that receptors for IgG Fc, C3b, and C3d on these cells are expressed equally well throughout the cell cycle, as evidenced by uptake experiments with radiolabeled human IgG and the fragments of C3 on synchronized cell cultures. However, cells used in these experiments were always obtained $72 \mathrm{~h}$ after initiation of the cultures.

Preparation of aggregated human gamma globulin ( $A H G$ ) and monomeric IgG. Human IgG was obtained from Cohn fraction II after fractionation on a DEAE-52 cellulose column with a $0.01 \mathrm{M}$ phosphate buffer, $\mathrm{pH}$ 7.3. Human IgG in phosphate-buffered saline (PBS) was freed from aggregates by centrifugation at $150,000 \mathrm{~g}$ for $90 \mathrm{~min}$; the upper third of the supernate (deaggregated or $7 \mathrm{~S} \mathrm{IgG)} \mathrm{was}$ removed, and the protein concentration was determined by an automated micro-Kjeldahl method (24). The 7S IgG was placed into samples of $0.1 \mathrm{ml}(6.5 \mathrm{mg} / \mathrm{ml})$, and stored at $-70^{\circ} \mathrm{C}$. AHG was prepared after heating a sample of 7S IgG in a waterbath at $63^{\circ} \mathrm{C}$ for $30 \mathrm{~min}$.

Antisera. Antiserum to human IgG was prepared in rabbits and the IgG fraction of this antiserum was isolated on a DEAE-52 column as above. Antiserum to human C3 (25) and antiserum to hepatitis $B$ surface antigen ( $\mathrm{HB}_{\mathrm{a}} \mathrm{Ag}$ ) were prepared in rabbits. The rabbit anti-HBa $-\mathrm{Ag}$ serum was conjugated with fluorescein isothiocyanate (FITC) (26). Antiserum specific to heavy chains of human IgG was purchased from Cappel Laboratories, Inc., (Downingtown, $\mathrm{Pa}$.)

Radioiodination of protein. Human 7S IgG, human IgM, bovine serum albumin (BSA), and the IgG fraction of the rabbit anti-human IgG serum were iodinated with ${ }^{225} \mathrm{I}$ according to the procedure of McConahey and Dixon (27). The specific activity of the ${ }^{125} \mathrm{I}$-rabbit anti-human IgG (1 $\mathrm{mg} / \mathrm{ml}$ ) was $0.2 \mu \mathrm{Ci} \mathrm{cpm} / \mu \mathrm{g}$ protein.

Sucrose density gradient ultracentrifugation. AHG was fractionated on a linear $10-37 \%$ sucrose density gradient in PBS, pH 7.2, formed in 5-ml cellulose nitrate tubes. The gradients were equilibrated to $4^{\circ} \mathrm{C}$ before the sample $(300$ $\mu 1$ of AHG in PBS, $3.5 \mathrm{mg} / \mathrm{ml}$ ) was applied. Ultracentrifugation was performed in an SW 50.1 rotor for $5 \mathrm{~h}$ at
$100,000 \mathrm{~g}$ and $4^{\circ} \mathrm{C}$ (Beckman Instruments, Inc., Spinco Div., Palo Alto, Calif.). 10-drop fractions were collected by piercing the tubes from below. Radiolabeled human IgM, human $7 \mathrm{~S} \mathrm{IgG}$, and BSA were used as $19 \mathrm{~S}, 7 \mathrm{~S}$, and $4.5 \mathrm{~S}$ markers, respectively. Aggregates of $95 \mathrm{~S}$ and smaller were retained on the gradient. Fractions containing aggregates of estimated size of $95 \mathrm{~S}-50 \mathrm{~S}, 49 \mathrm{~S}-35 \mathrm{~S}, 34 \mathrm{~S}-19 \mathrm{~S}, 18 \mathrm{~S}-11 \mathrm{~S}$, and $10 \mathrm{~S}-7 \mathrm{~S}$ were pooled and dialyzed overnight in PBS. Subsequently, the protein content in each pool was determined as above. These pools were used in experiments in which the effect of the size of aggregates on binding by $C$ receptors of Raji cells was ascertained.

Selected sera from patients with hepatitis and malignancies were also fractionated on similar $10-37 \%$ sucrose gradients by centrifugation at $100,000 \mathrm{~g}$ for $18 \mathrm{~h}$. 10-drop fractions were collected from the tubes and checked for the position of $\mathrm{C} 3$ and $\mathrm{HB}_{\mathrm{a}}-\mathrm{Ag}$ by Ouchterlony analysis and for the distribution of the IgG by radial immunodiffusion (28).

Raji cell radioimmune assay for detecting and quantitating immune complexes in human sera. In checking human sera for immune complexes, $2 \times 10^{\circ}$ Raji cells in $50 \mu \mathrm{l}$ MEM were reacted with $25 \mu 1$ of a $1: 4$ dilution in saline of the serum to be tested. After an incubation period of 45 min at $37^{\circ} \mathrm{C}$ with gentle shaking, cells were washed three times with $\mathrm{MEM}$, reacted $\left(30 \mathrm{~min}, 4^{\circ} \mathrm{C}\right)$ with an optimum amount of a $1: 2$ dilution of ${ }^{125} \mathrm{I}$-rabbit anti-human IgG in MEM containing $1 \%$ human serum albumin (MEM-HSA), and gently shaken. Subsequently cells were washed three times with MEM-HSA, and radioactivity in the cell pellet was determined in a gamma counter. The amount of uptake then was referred to a standard curve of radioactive antibody uptake by cells incubated with $25 \mu$ l of a 1:4 final dilution of normal human serum (NHS), freshly obtained or stored at $-70^{\circ} \mathrm{C}$, or of a pool of 20 NHS (sources of C) to which various amounts (from $10 \mu \mathrm{g}$ to $10 \mathrm{ng}$ ) of AHG had been added. The mixtures of NHS or pooled NHS with various amounts of AHG had been preincubated for $30 \mathrm{~min}$ at $37^{\circ} \mathrm{C}$ before being added to cells. The amount of complexes in each serum tested was expressed as micrograms AHG equivalent per milliliter of serum.

Aggregates used in this test were freshly made each day from samples of $7 \mathrm{~S} \mathrm{IgG,} \mathrm{stored} \mathrm{at}-70^{\circ} \mathrm{C}$ as described above. Just before use, the aggregates were centrifuged at $1,500 \mathrm{~g}$ for $15 \mathrm{~min}$ to remove insoluble large aggregates. Preliminary studies with sucrose gradients had shown that aggregates prepared from day to day under the same conditions showed very little variation in patterns of protein distribution along the gradient. However, to ensure uniformity in the size of aggregates in later experiments, a large batch of AHG was prepared and $0.1-\mathrm{ml}$ samples of this preparation were stored at $-70^{\circ} \mathrm{C}$. Thus the standard curve was highly reproducible. AHG stored at $-70^{\circ} \mathrm{C}$ was stable for $1 \mathrm{mo}$, but showed a gradual decline in activity over longer periods of time.

Experimental sera. Samples of 19 sera were obtained from patients with acute hepatitis with $\mathrm{HBs}-\mathrm{Ag}, 15$ were from patients with acute hepatitis without $\mathrm{HB}_{\mathrm{B}}-\mathrm{Ag}$, and 59 were from asymptomatic carriers of $\mathrm{HB}_{\mathrm{s}}-\mathrm{Ag}$. The presence of $\mathrm{HB}_{\mathbf{s}}-\mathrm{Ag}$ was determined by counterimmunoelectrophoresis (29). From eight of the above patients with acute hepatitis and $\mathrm{HB}_{\mathbf{s}}-\mathrm{Ag}$, sera were also obtained at the convalescent phase ( 3 mo after the onset of the disease). These sera were provided by Dr. G. R. Irwin (Walter Reed Army Medical Center, Washington, D. C.). Serum samples of 13 patients with systemic lupus erythematosus (SLE) were sent to us by Drs. H. G. Kunkel and J. B. Winfield (Rocke- 
feller University, New York). Only one serum specimen each was available from three of these patients. From the remaining 10 patients a total of 92 sera obtained from serial monthly bleedings were provided. 25 sera from patients with various forms of vasculitis were obtained from Drs. K. F. Austen and N. A. Soter (Harvard Medical School, Boston, Mass.) and from Dr. J. S. Johnson (Scripps Clinic). Six sera and cerebrospinal fluids from patients with subacute sclerosing panencephalitis (SSPE) were provided by Dr. M. B. A. Oldstone (Scripps Clinic). 119 sera from serial bleedings of 20 patients with various grades of dengue hemorrhagic fever (DHF) were provided by Dr. V. A. Bokisch (Scripps Clinic). 84 sera were collected from patients with malignancies and were given to us by Drs. T. J. Lehar and D. R. Newman (Rees-Stealy Medical Clinic, San Diego, Calif.). In addition 20 sera from patients with African Burkitt's lymphoma were from Dr. G. Klein (Karolinska Institutet, Stockholm, Sweden).

Finally, as controls, 120 sera from healthy laboratory personnel and military recruits and 60 sera from hospitalized patients with no suspected immune complex disease (hypertension, diabetes, heart failure, or obstructive pulmonary disease) were tested. All sera tested by the Raji cell radioimmune assay had been frozen at $-70^{\circ} \mathrm{C}$ and thawed once.

Data on the diagnosis, activity of the disease, and appropriate laboratory findings for each condition studied, such as DNA-binding capacity and $\mathrm{C}^{\prime} \mathrm{H}_{\mathrm{so}}$ levels in SLE patients, and presence or absence of $\mathrm{HB}_{\mathrm{s}}-\mathrm{Ag}$ and serum enzyme levels in hepatitis patients, were kindly provided to us by the respective investigators after the results of the Raji cell test had been obtained.

Statistical analysis. The mean, standard deviation, and standard error of radioactivity (cpm) were calculated for duplicate samples of the standard curve and each group of triplicate serum samples.

\section{RESULTS}

Quantitation of IgG bound to Raji cells' IgG Fc and $C$ receptors. Since IgG Fc receptors on Raji cells bind both AHG and 7S IgG, and immune complexes or AHG reacted with $C$ bind to these cells only via receptors for C $(20,22)$, we assessed the number of IgG molecules that bound to Raji cells' IgG Fc and C receptors. As depicted in Fig. 1, approximately eight times more AHG bound to cells after exposure to fresh rather than heated $\left(56^{\circ} \mathrm{C}, 30 \mathrm{~min}\right)$ serum. At saturation, approximately $8.5 \times 10^{5}$ molecules of AHG bound/Raji cell via $\mathrm{C}$ receptors and only $1.2 \times 10^{s}$ molecules via IgG Fc receptors. When $7 \mathrm{~S} \mathrm{IgG}$ was added to cells, approximately $9 \times 10^{4}$ molecules bound/cell. The results indicated that binding of AHG to Raji cells is greatly enhanced in the presence of active $\mathrm{C}$.

Detection of $A H G$ in NHS by measuring uptake of radioactive antibody to human IgG by Raji cells. Our eventual purpose was to use the $C$ receptors on Raji cells for the demonstration and quantitation of immune complexes in human sera. Therefore, the efficiency of Raji cells in detecting immune complexes in sera was first tested by incubating them with NHS containing various concentrations of AHG, then measuring their uptake of radioactive rabbit anti-human IgG. AHG was used as

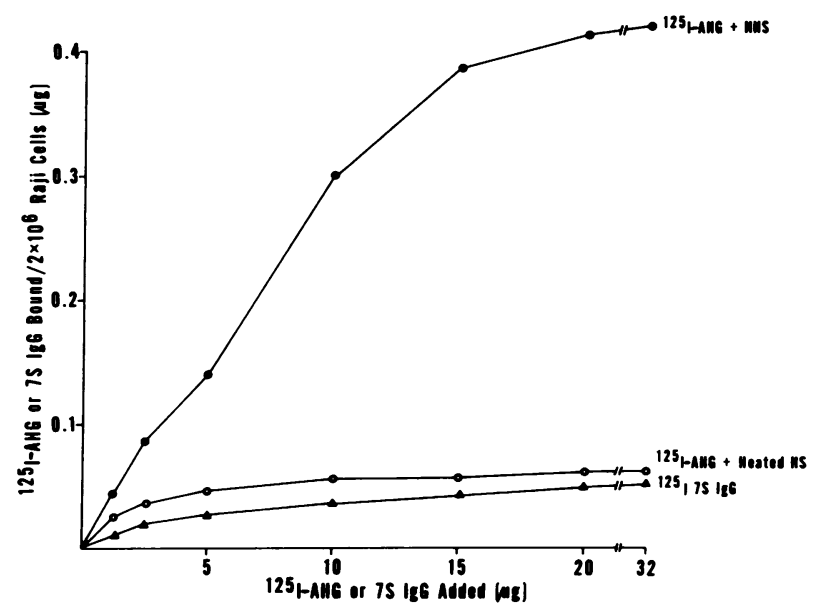

FIgURE 1 Uptake of ${ }^{10} \mathrm{I}-\mathrm{AHG}$ and $7 \mathrm{~S}$ IgG by $\mathrm{C}$ and Fc receptors on Raji cells. $2 \times 10^{\circ}$ Raji cells were incubated $\left(37^{\circ} \mathrm{C}, 30 \mathrm{~min}\right)$ with increasing amounts of ${ }^{120} \mathrm{I}-\mathrm{AHG}$ that had been first reacted $\left(37^{\circ} \mathrm{C}, 30 \mathrm{~min}\right)$ with $25 \mu \mathrm{l}$ fresh or heated $\left(56^{\circ} \mathrm{C}, 30 \mathrm{~min}\right)$ human serum, and $7 \mathrm{~S}{ }^{105} \mathrm{I}-\mathrm{IgG}$ in saline.

an in vitro model of human immune complexes. Even at a concentration of $40 \mathrm{ng}$ AHG in $25 \mu \mathrm{l}$ of $1: 4$ serum $(6 \mu \mathrm{g} / \mathrm{ml})$, the uptake of radioactive antibody was considerably greater than that by cells incubated with NHS without AHG (Fig. 2). The amount of radioactive antibody taken up by the cells was directly related to the amount of AHG present in the serum (Fig. 2). For

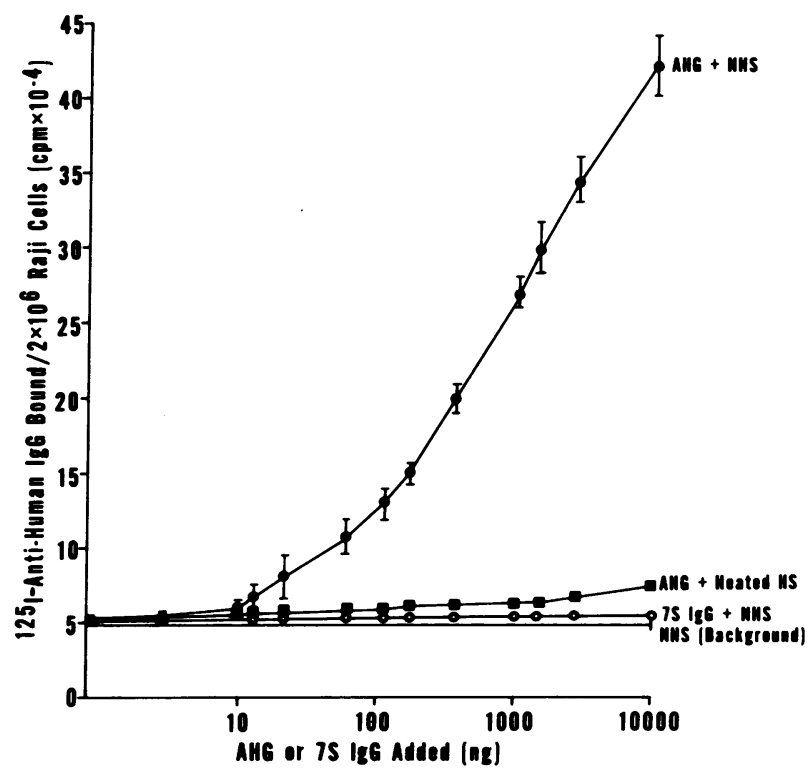

FIGURE 2 Raji cell uptake of ${ }^{10}$ I-anti-human Ig after incubation with increasing amounts of AHG in fresh or heated $\left(56^{\circ} \mathrm{C}, 30 \mathrm{~min}\right)$ human serum, and $7 \mathrm{~S} \mathrm{IgG} \mathrm{in} \mathrm{NHS.}$ Each point of the AHG + NHS curve represents the mean \pm 2 SD of duplicate samples run on 3 consecutive days. 


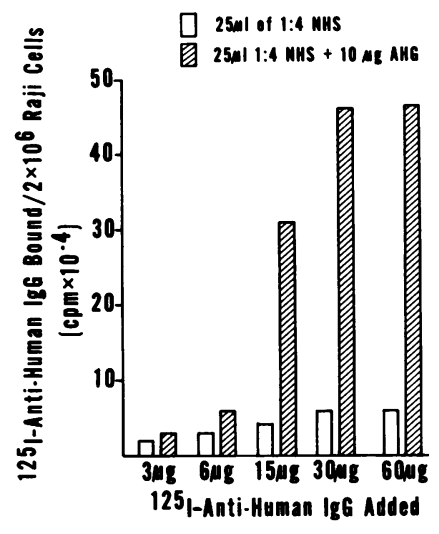

FIgURE 3 Titration of ${ }^{125} \mathrm{I}$-anti-human IgG for the demonstration of AHG in serum. $2 \times 10^{\circ} \mathrm{Raji}$ cells were incubated $\left(37^{\circ} \mathrm{C}, 45 \mathrm{~min}\right)$ with $25 \mu \mathrm{l}$ of $1: 4$ dilution of NHS that had been first incubated $\left(37^{\circ} \mathrm{C}, 30 \mathrm{~min}\right)$ with or without $10 \mu \mathrm{g}$ AHG. The washed cells were reacted $\left(4^{\circ} \mathrm{C}, 30\right.$ $\mathrm{min}$ ) with increasing amounts of ${ }^{125} \mathrm{I}$-anti-human $\mathrm{Ig}$ and the washed cell pellets were counted.

comparison, the amount of radioactive antibody bound to cells incubated with similar concentrations of AHG in heated $\left(56^{\circ} \mathrm{C}, 30 \mathrm{~min}\right)$ human serum or $7 \mathrm{~S} \mathrm{IgG}$ in fresh serum is also shown in Fig. 2. Over the range tested, addition of AHG in heated human serum or $7 \mathrm{~S} \mathrm{IgG} \mathrm{in}$ NHS did not increase uptake of radioactive antihuman IgG by the cells over that observed with serum alone. The results showed that $\mathrm{C}$ receptors on Raji cells can efficiently be used for the detection and quantitation of immune complexes or AHG with fixed C.

Titration of radiolabeled anti-human IgG for the demonstration of $A H G$ in serum. Raji cells reacted with NHS bind IgG only via Fc receptors. In contrast, cells incubated with sera containing IgG complexes with fixed $\mathrm{C}$ bind native $\mathrm{IgG}$ via $\mathrm{Fc}$ receptors and complexed IgG via $C$ receptors $(20)$. To detect the difference in radioactive antibody uptake between cells incubated in sera with or without complexes, an excess of that amount of antibody needed to react with the molecules of native IgG bound via Fc receptors must be offered to the cells. As in Fig. 3, when $30 \mu \mathrm{g}$ of radioactive antibody was added to cells incubated with $25 \mu 1$ of $1: 4 \mathrm{NHS}$ in saline alone or containing $10 \mu \mathrm{g}$ of $\mathrm{AHG}$, uptake by the latter was approximately ninefold greater. However, with 10 times less antibody, the uptake between cells incubated with NHS alone or NHS containing AHG was equivalent. The use of more than $30 \mu \mathrm{g}$ of antibody did not increase the difference in uptake between NHS alone and NHS containing AHG, indicating that $30 \mu \mathrm{g}$ of the radioactive antibody saturated both $7 \mathrm{~S}$ IgG bound via Fc receptors and $A H G$ bound via $\mathrm{C}$ receptors.

Effect of the aggregates' size on their detection by Raji cells. Since large aggregates of IgG fix C better than small ones $(7,30,31)$, and large aggregates or im- mune complexes made near equivalence bind to $\mathrm{C}$ receptors better than smaller aggregates or immune complexes made at large antigen excess $(22,32)$, it was important to test the Raji cells' ability to detect aggregates of different sizes. Uptake of radioactive antibody by Raji cells incubated with NHS alone and with NHS containing unfractionated AHG or aggregates of defined sizes is compared in Fig. 4. It is evident that uptake of radioactive antibody was directly related to the size of aggregates. With the same amounts of 35S-95S AHG and unfractionated $\mathrm{AHG}$, cells took up comparable amounts of radioactive antibody. However, with AHG of $34 \mathrm{~S}-19 \mathrm{~S}$ and $18 \mathrm{~S}-11 \mathrm{~S}$, the cells took up approximately one half to one third the radioactive antibody taken up after incubation with serum containing comparable amounts of unfractionated AHG (Fig. 4). Therefore, whereas the sensitivity of the Raji cells in detecting unfractionated AHG in serum was approximately 6 $\mu \mathrm{g} / \mathrm{ml}$, with $34 \mathrm{~S}-19 \mathrm{~S}$ AHG it dropped to $25 \mu \mathrm{g} / \mathrm{ml}$ and with $18 \mathrm{~S}-11 \mathrm{~S}$ to $50 \mu \mathrm{g} / \mathrm{ml}$.

The effect of excess $C$ on the binding of $A H G$ with fixed $C$ to Raji cells' $C$ receptors. Receptors for C3b on Raji cells are the same or closely associated with the receptors for $\mathrm{C} 3$ (33), and immune complexes or AHG reacted with $\mathrm{C}$ bind to cells via both $\mathrm{C} 3-\mathrm{C} 3 \mathrm{~b}$ and $\mathrm{C3d}$ receptors (20). Since free C3 may compete with immune complex-bound $\mathrm{C} 3 \mathrm{~b}$ for the $\mathrm{C} 3-\mathrm{C} 3 \mathrm{~b}$ receptor sites, the effect of excess $\mathrm{C}$ on the binding of AHG with fixed $\mathrm{C}$ to Raji cells was assessed. In Fig. 5 the uptake of dilutions of ${ }^{120} \mathrm{I}$-AHG incubated with $25 \mu$ l of neat, $1: 2$, $1: 4$, and $1: 8$ dilutions of NHS is shown. It is evident that binding of $15 \mu \mathrm{g}{ }^{125} \mathrm{I}-\mathrm{AHG}$ was higher when neat rather than diluted serum was used as a source of $C$.

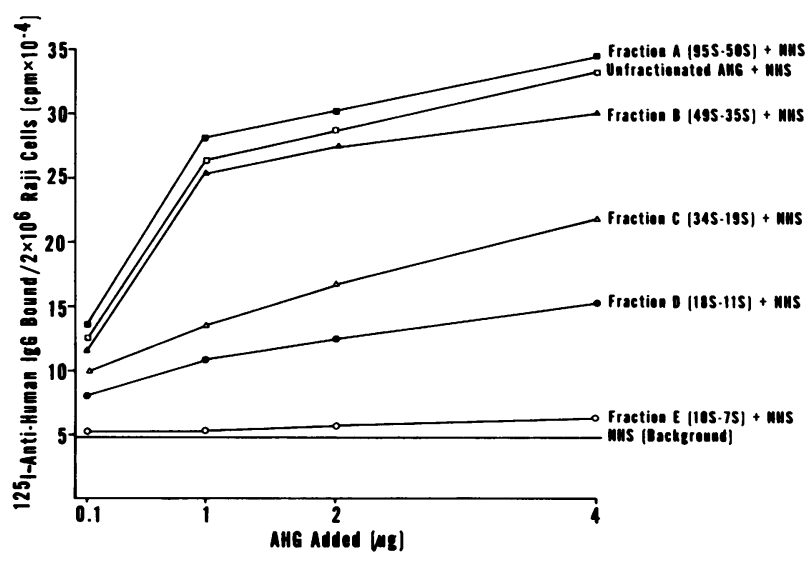

FIgURE 4 Effect of size on detection of AHG by Raji cells' C receptors. $2 \times 10^{8}$ Raji cells were incubated with $25 \mu l$ of $1: 4$ final dilution of NHS containing increasing amounts of unfractionated AHG or AHG of defined sizes. The washed cells were reacted with ${ }^{100} \mathrm{I}$-anti-IgG and the uptake was measured. 


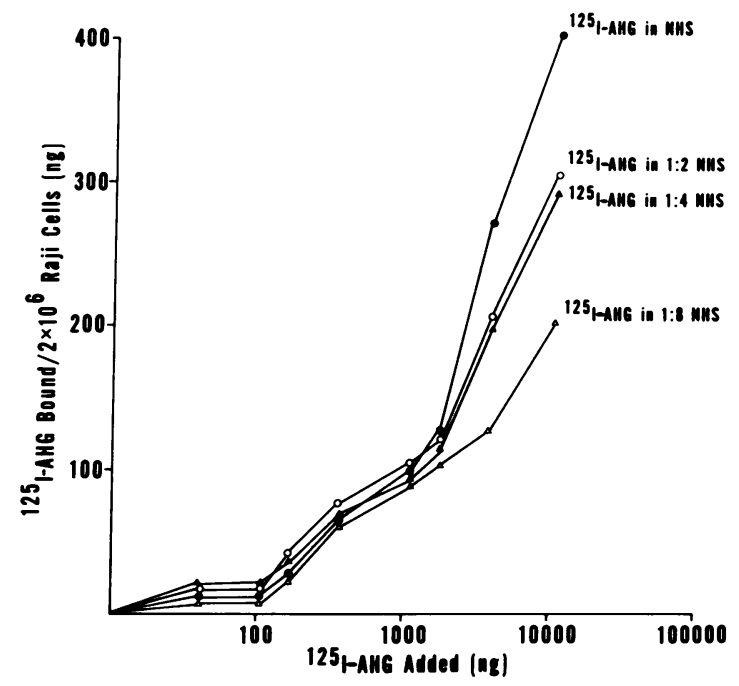

FIGURE 5 Raji cell uptake of ${ }^{125}$ I-AHG in NHS as a C source. $2 \times 10^{8}$ Raji cells were incubated with increasing amounts of ${ }^{125} \mathrm{I}-\mathrm{AHG}$ which had been first reacted with 25 $\mu 1$ of neat, $1: 2,1: 4$, and $1: 8$ dilutions of NHS in saline.

However, with smaller amounts of AHG, the difference in uptake between AHG in neat serum and in diluted serum became less evident, suggesting an inhibitory effect of excess $\mathrm{C}$ on binding. In another, more direct approach, $15 \mu \mathrm{g}$ of ${ }^{125} \mathrm{I}-\mathrm{AHG}$ was incubated $(30 \mathrm{~min}$, $37^{\circ} \mathrm{C}$ ) with increasing amounts of NHS and then added to $2 \times 10^{8}$ Raji cells. The uptake of this amount of AHG was optimum when 40-50 $\mu 1$ of NHS was used. With larger amounts of serum, uptake was partially inhibited (Fig. 6). This inhibition was not greater than $50 \%$ of the optimal uptake, and even with a large excess of $C$ did not descend to the low uptake observed with AHG without fixed $\mathrm{C}$ (Fig. 6). The results showed that an excess of $\mathrm{C}$ had some inhibitory effect on the binding of complexes with fixed C. Because of this C effect, a $1: 4$ dilution of serum was chosen as optimum for study of unknown test samples as well as for obtaining the standard curve.

To demonstrate further that inhibition resulted from excess free $\mathrm{C} 3$ and not from other serum factors, we determined the percent of $5 \mu \mathrm{g}{ }^{185} \mathrm{I}-\mathrm{AHG}$ taken up by Raji cells incubated with the AHG and $100 \mu 1$ neat or diluted 1:4 NHS. Similarly, we determined the uptake by cells of ${ }^{120} \mathrm{I}-\mathrm{AHG}$ first incubated $\left(37^{\circ} \mathrm{C}, 30 \mathrm{~min}\right)$ with $100 \mu 1$ neat or $1: 4$ serum and then reacted with $1 \mathrm{mg}$ zymosan $\left(37^{\circ} \mathrm{C}, 30 \mathrm{~min}\right)$, which activates and removes residual $\mathrm{C}$ not bound to immune complexes. As shown in Fig. 7, uptake of AHG in neat serum was lower than that observed in diluted serum. However, uptake of AHG in neat serum increased after removal of excess C, possibly C3, by zymosan (Fig. 7).

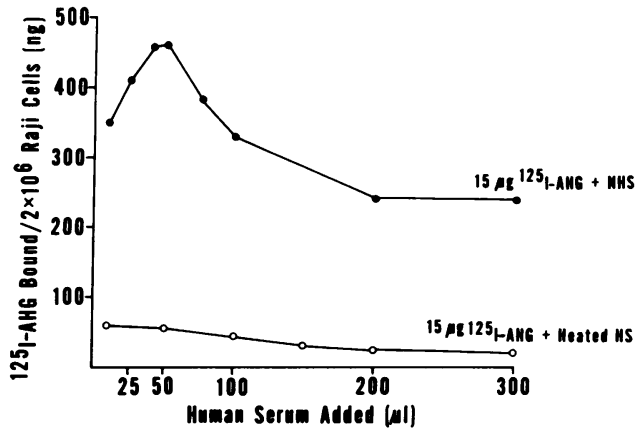

Figure 6 Effect of excess $\mathrm{C}$ on the binding of ${ }^{125} \mathrm{I}$-AHG to Raji cells' C receptors. Binding of AHG to C receptors was partially inhibited by excess fresh NHS. Binding of AHG to $\mathrm{Fc}$ receptors was low but still inhibited by excess 7S IgG in heated human serum.

Detection and quantitation of immune complexes in human sera. Since Raji cells efficiently bind AHG reacted with serum, these cells were used in a radioimmune assay system for the detection and quantitation of circulating immune complexes in humans. Accordingly, cells were incubated with the serum to be tested and then reacted with an optimal amount of radioactive antibody to human IgG. Subsequently the uptake was determined and referred to a standard curve of radioactive antibody uptake by cells previously incubated with various amounts of AHG in serum. A base line of radioactive antibody uptake by cells incubated with NHS or a pool of NHS, used as sources of $\mathrm{C}$ in the reference curve, was also established. The estimated amount of complexes in each serum tested was expressed as micrograms AHG equivalent per milliliter serum. Using this method to determine

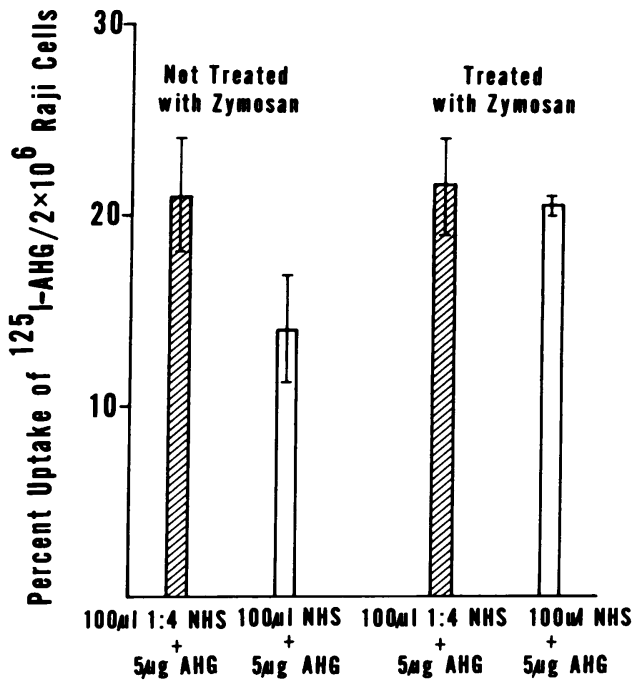

FIgURE 7 Enhanced binding of ${ }^{125} \mathrm{I}-\mathrm{AHG}$ to Raji cells' C receptors after depletion of residual $\mathrm{C}$ by zymosan. Values represent mean $\pm 1 \mathrm{SD}$ for three experiments. 
TABLE I

Raji Cell Radioimmune Assay for Immune Complexes in Human Sera

\begin{tabular}{|c|c|c|c|c|c|}
\hline \multirow[b]{2}{*}{ Diagnosis } & \multirow{2}{*}{$\begin{array}{c}\text { No. } \\
\text { cases }\end{array}$} & \multirow{2}{*}{$\begin{array}{c}\text { No. } \\
\text { cases } \\
\text { positive }\end{array}$} & \multirow[b]{2}{*}{ Positive } & \multicolumn{2}{|c|}{ AHG } \\
\hline & & & & Mean & Range \\
\hline & & & $\%$ & \multicolumn{2}{|c|}{$\mu g e q / m l$} \\
\hline $\begin{array}{l}\text { Serum hepatitis } \\
\text { (with or without } \mathrm{HB}_{\mathbf{g}}-\mathbf{A g} \text { ) }\end{array}$ & 34 & 18 & 52.9 & 65 & 24-212 \\
\hline SLE & 13 & 13 & 100 & 327 & $24-1,100$ \\
\hline Vasculitis & 25 & 14 & 56 & 193 & $25-1,000$ \\
\hline SSPE & 6 & 3 & 50 & 58 & $24-100$ \\
\hline DHF & 24 & 15 & 62 & 62 & $25-225$ \\
\hline Malignancies & 104 & 43 & 41 & 68 & $20-383$ \\
\hline Hospitalized patients & 60 & 5 & 8.3 & 39 & $20-100$ \\
\hline Normal patients & 120 & 4 & 3.3 & 21 & $12-30$ \\
\hline
\end{tabular}

the amount of IgG complexes, we were able to detect more than $12 \mu \mathrm{g}$ AHG equivalent, a level exceeding the upper limits of normal, in the sera of $52.9 \%$ of patients with acute serum hepatitis with or without $\mathrm{HB}_{\mathrm{s}} \mathrm{Ag}$, $100 \%$ of patients with SLE, $56 \%$ of patients with various vasculitides, $50 \%$ of patients with SSPE; $62 \%$ of patients with DHF and $41 \%$ of patients with various malignancies. In contrast, only $3.3 \%$ of normal donors and $8.3 \%$ of hospitalized patients with suspected immune complex disease exceeded the upper normal limit of $12 \mu \mathrm{g}$ AHG eq/ml (Table I). When the four normal sera found to contain low levels of immune complexes (never exceeding $30 \mu \mathrm{g}$ AHG eq/ml) were tested by an indirect immunofluorescence method for antinuclear antibodies (34), they all were positive, with titers of $1: 4$ to $1: 32$.

In sera of patients with acute hepatitis with and without $\mathrm{HB}_{\mathrm{s}}-\mathrm{Ag}$, and asymptomatic carriers of $\mathrm{HB}_{\mathrm{s}}-\mathrm{AG}$, the Raji cell assay detected immune complexes (Table II) with a mean value of $55-68 \mu \mathrm{g}$ AHG eq/ml serum. Results from the Raji cell assay of sera from patients with acute hepatitis and $\mathrm{HB}_{\mathrm{s}}-\mathrm{Ag}$ obtained at the acute and

TABLE II

Raji Cell Radioimmune Assay for Immune Complexes in Patients with Acute Hepatitis with $\mathrm{HB}$ - $\mathrm{Ag}$, Acute Hepatitis without $H B_{s}-A g$, and in Asymptomatic Carriers of $\mathrm{HB}_{\mathrm{s}}-\mathrm{Ag}$

\begin{tabular}{|c|c|c|c|c|c|}
\hline \multirow[b]{2}{*}{ Diagnosis } & \multirow{2}{*}{$\begin{array}{l}\text { No. } \\
\text { cases }\end{array}$} & \multirow{2}{*}{$\begin{array}{l}\text { No. } \\
\text { positive }\end{array}$} & \multirow[b]{2}{*}{ Positive } & \multicolumn{2}{|c|}{ AHG } \\
\hline & & & & Mean & Range \\
\hline & & & $\%$ & \multicolumn{2}{|c|}{$\mu g e q / m l$} \\
\hline $\begin{array}{r}\text { Acute hepatitis } \\
\text { with } \mathrm{HB}_{\mathrm{g}}-\mathrm{Ag}\end{array}$ & 19 & 12 & 63.1 & 68 & $(24-212)$ \\
\hline $\begin{array}{l}\text { Acute hepatitis } \\
\text { without } \mathrm{HB}_{\mathbf{s}}-\mathbf{A g} \\
\text { Asymptotomatic carriers }\end{array}$ & 15 & 6 & 40 & 62 & $(24-155)$ \\
\hline of $\mathrm{HB}_{\mathbf{s}}-\mathbf{A g}$ & 59 & 8 & 13.5 & 55 & $(24-100)$ \\
\hline
\end{tabular}

TABLE III

Raji Cell Radioimmune Assay for Immune Complexes in Patients with Acute Hepatitis and $\mathrm{HB} \cdot-\mathrm{Ag}$

\begin{tabular}{clrrrr}
\hline $\begin{array}{c}\text { Serum } \\
\text { no. }\end{array}$ & Phase of disease & AHG & $\begin{array}{c}\text { Serum } \\
\text { total } \\
\text { bilirubin }\end{array}$ & SGOT & IgG \\
\hline & & $\mu g$ eq/ml & mg/l00 $m l$ & U /liter & $m g / m l$ \\
1 & Acute & 84 & 1.4 & 180 & 10.5 \\
& Convalescent* & 24 & 0.5 & 20 & 9.5 \\
2 & Acute & 77 & 1.8 & 120 & 13.0 \\
& Convalescent & 50 & 0.5 & 25 & 12.0 \\
3 & Acute & 200 & 10.2 & 1,300 & 15.5 \\
& Convalescent & 0 & 0.8 & 35 & ND \\
4 & Acute & 115 & 4.7 & 2,100 & 11.5 \\
& Convalescent & 100 & 0.6 & 40 & 10.7 \\
5 & Acute & 54 & ND & ND & 16.5 \\
& Convalescent & 20 & ND & ND & 16.0 \\
6 & Acute & 100 & 10.0 & 1,400 & 9.5 \\
& Convalescent & 50 & 0.5 & 25 & 10.0 \\
7 & Acute & 50 & 2.5 & 600 & 18.5 \\
& Convalescent & 45 & 0.6 & 25 & 15.5 \\
8 & Acute & 95 & ND & ND & 10.5 \\
& Convalescent & 50 & ND & ND & 13.0 \\
\hline
\end{tabular}

* Convalescent phase, 3 mo after the onset of the disease.

$\ddagger$ ND, not determined.

at the convalescent phases of their disease are shown in Table III and compared with total bilirubin levels, SGOT, and IgG levels. In the majority of these patients, the amount of complexes as detected by the Raji cell assay diminished markedly as the elevated serum enzyme levels fell during convalescence. However, the amount of complexes in two patients remained approximately the same as serum enzyme levels declined. No correlation between the amount of complexes and levels of serum $\mathrm{IgG}$ was observed.

We then wished to demonstrate whether the complexes detected on Raji cells after reaction with hepatitis sera were due to the presence of $\mathrm{HB}$-Ag-antibody-C complexes. Five sera positive for immune complexes from patients with acute hepatitis and $\mathrm{HB}_{\mathrm{s}} \mathrm{Ag}$ and three sera negative for immune complexes from asymptomatic carriers of $\mathrm{HB}_{\mathrm{s}} \mathrm{Ag}$ were fractionated on a $10-37 \%$ sucrose gradient. Fractions collected were checked for the presence of $\mathrm{HB}_{\mathrm{s}}-\mathrm{Ag}$ and $\mathrm{C} 3$ by double immunodiffusion and for the distribution of IgG by radial immunodiffusion. Representative profiles of the sucrose gradients from one patient who was positive and one who was negative for immune complexes are shown in Fig. 8. $\mathrm{HB}_{\mathrm{s}} \mathrm{Ag}, \mathrm{C3}$, and IgG were all detected in approximately the middle portion of the gradient of sera from asymptomatic carriers negative for immune complexes. In contrast, in sera from patients with acute hepatitis who had immune complexes, all $\mathrm{HB}_{\mathrm{a}} \mathrm{-Ag}$ plus $\mathrm{C} 3$ and IgG were present in the lower fractions of the gradients. These results suggested that the complexes found in patients with hepatitis were composed of $\mathrm{HB}_{\mathrm{s}-}$ Ag-antibody and C. When Raji cells were incubated 


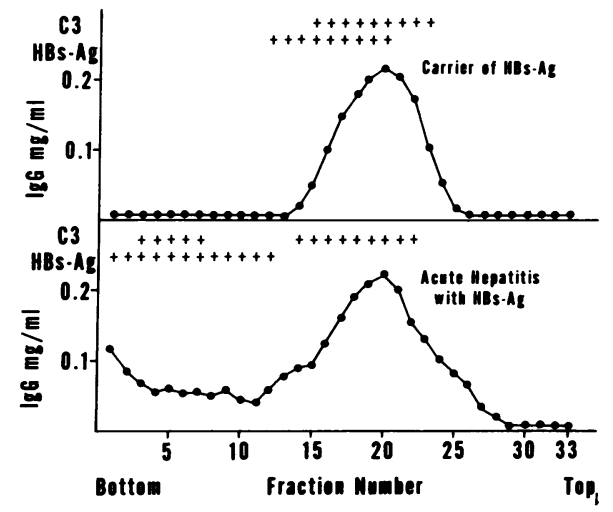

FIGURE 8 Sucrose density gradient fractionation of sera from an asymptomatic carrier of $\mathrm{HB}_{\mathbf{s}}-\mathrm{Ag}$ negative for immune complexes (upper panel) and a patient with acute hepatitis and $\mathrm{HB}_{\mathbf{s}}-\mathrm{Ag}$ having immune complexes (lower panel). Fractions in which $\mathrm{C3}$ and $\mathrm{HB}_{\mathrm{s}}-\mathrm{Ag}$ were detected are shown $(+)$ at the top of each panel. The distribution of IgG in each fraction is also indicated (-

with the dialyzed lower portion of the gradient from the sera of patients with hepatitis who were positive for immune complexes and stained with FITC rabbit anti-HBs-Ag, the cells were fluorescence positive, indicating the presence of this antigen on their surfaces. Control cells first incubated with NHS, MEM, purified $\mathrm{HB}_{\mathrm{s}}-\mathrm{Ag}$, or the middle portion of the gradients from sera negative for immune complexes had no detectable $\mathrm{HB}_{\mathrm{s}} \mathrm{Ag}$ on their surfaces when stained with FITC anti $\mathrm{HB}_{\mathbf{s}}$-Ag.

Sera from patients with SLE were also analyzed by the Raji cell assay. Immune complexes, particularly of the DNA-anti-DNA type, have been implicated in the pathogenesis of this disease $(17,35)$. As shown in Table IV, all patients tested had immune complexes. A negative correlation existed between amount of complexes and total hemolytic complement, as well as a positive correlation between amount of complexes and anti-nativeDNA antibody levels. The amount of immune complexes in all but one (Tit) correlated excellently with activity of the disease, as evidenced by clinical criteria. No correlation between amount of complexes present and serum IgG levels was observed. When serial monthly bleedings obtained over a long period of time (1-2 yr) from 10 of these patients were analyzed, in all but one (Tit), positive results from the Raji cell test and exacerbations of the disease correlated well. Fig. 9 illustrates the course of the disease and the results of the Raji cell test in one of these patients (Ham). The correlation is striking between clear-cut flare of SLE (fever, pleuritis), $\mathrm{C}^{\prime} \mathrm{H}_{50}$ depression, presence of antibodies to DNA, and positive results by the Raji cell radioimmune assay. All indices rapidly returned toward normal after prednisone treatment began.
TABLE IV

Raji Cell Radioimmune Assay for Immune Complexes in Patients with SLE

\begin{tabular}{|c|c|c|c|c|c|c|c|}
\hline Subject & AHG & $\mathrm{C}^{\prime} \mathrm{H}_{60^{*}}$ & $\begin{array}{c}\text { anti- } \\
\text { DNA }\end{array}$ & $\begin{array}{c}\text { Erythro- } \\
\text { cyte } \\
\text { sedimen- } \\
\text { tation } \\
\text { rate }\end{array}$ & $\begin{array}{c}\text { Protein- } \\
\text { uria }\end{array}$ & $\begin{array}{r}\text { - Clinical } \\
\text { activity }\end{array}$ & IgG \\
\hline & $\mu g \mathrm{eq} / \mathrm{ml}$ & & & & & & $m g / m l$ \\
\hline Cia & 24 & 200 & ND\& & 10 & ND & 0 & 14 \\
\hline Hen & 98 & 85 & 43 & 39 & ND & + & 13.5 \\
\hline Int & 25 & 141 & 5 & 54 & ND & 0 & 15.7 \\
\hline Har & 400 & 114 & 55 & 92 & 0 & + & 18.5 \\
\hline $\mathrm{Wg}$ & 24 & 125 & 34 & 69 & \pm & \pm & 14.9 \\
\hline McInt & 65 & 147 & ND & 24 & \pm & \pm & 12.3 \\
\hline Dep & 175 & 93 & 51 & 58 & \pm & + & 12.6 \\
\hline Esp & 325 & 78 & 51 & 47 & + & + & 13.5 \\
\hline Ham & 1,000 & $<30$ & 62 & 15 & 0 & + & 11.8 \\
\hline Gro & 164 & $<30$ & 49 & 75 & + & + & 17.0 \\
\hline Tit & 428 & 200 & ND & 89 & 0 & 0 & 11.0 \\
\hline Col & 52 & 121 & ND & 35 & 0 & 0 & ND \\
\hline Ber & 800 & 74 & 57 & 26 & 0 & + & 14.7 \\
\hline
\end{tabular}

* Normal values $>150$.

$\ddagger$ Determined by the Farr technique with $\left[{ }^{14} \mathrm{C}\right] \mathrm{DNA}$. Upper limit for normals $26 \%$ binding.

$\S \mathrm{ND}$, not determined.

In our experiments the amount of $\operatorname{IgG}$ bound to Raji cells was determined by using radiolabeled anti-IgG antibody reacting against both heavy and light chains. However, it has been reported that many SLE sera contain antilymphocyte cold-reactive antibodies mainly of the IgM class $(36,37)$. To demonstrate that absorption of

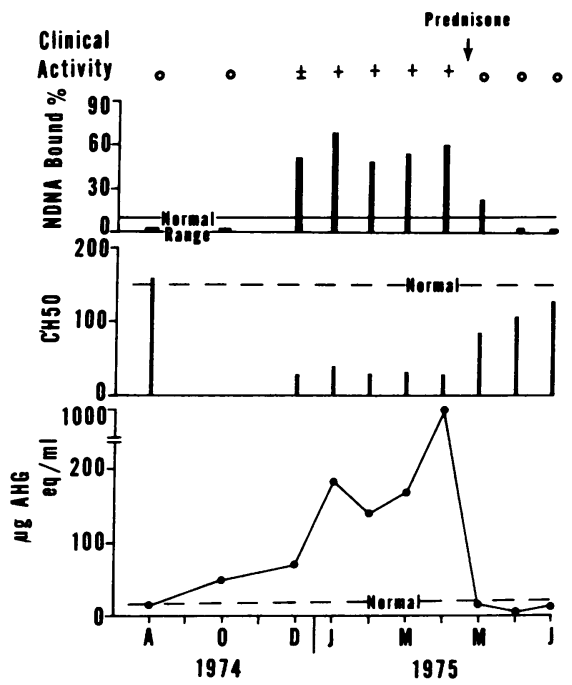

FIGURE 9 Serial study of a 47-yr-old women (Ham) with SLE shows the correlation among levels of immune complexes, $\mathrm{C}^{\prime} \mathrm{H} 50$, antibodies to native (N)DNA, and clinical activity. 
TABLE V

Failure of Cold-Reactive IgM Antilymphocyte Antibodies to Absorb to Raji Cells at $37^{\circ} \mathrm{C}$

\begin{tabular}{llcc}
\hline \multicolumn{1}{c}{ Subject } & $\begin{array}{c}\text { Ig class of } \\
\text { Antilymphocyte } \\
\text { antibody* }\end{array}$ & $\begin{array}{c}\text { 1 } 25 \text { I-anti-IgG } \\
\text { (heavy } \\
\text { + light } \\
\text { chains) }\end{array}$ & $\begin{array}{c}\text { 125I-anti-IgG } \\
\text { (heavy } \\
\text { chains) }\end{array}$ \\
\hline Hen & IgM + (IgG) $\ddagger$ & 101 & 98 \\
Har & IgM + (IgG) & 400 & 383 \\
Berg & IgM + (IgG) & 800 & 774 \\
Esp & IgM & 325 & 301 \\
Dep & IgM & 175 & 178 \\
\hline
\end{tabular}

* The class of cold-reactive antilymphocyte antibody in these patients has been previously determined by Winfield et al. (37).

$\ddagger$ In patients Hen, Har, and Berg, the studies of Winfield et al. (37) showed that the bulk of antilymphocyte antibodies were of the IgM class. However, presence of a small amount of IgG cold-reactive antibodies was also suspected.

\$ The amount of complexes in the sera was estimated by using standard curves obtained with cells incubated with AHG containing $\mathrm{C}$ and reacted with ${ }^{125} \mathrm{I}$-anti-IgG (heavy + light chains) or with ${ }^{125}$ I-IgG (heavy chain-specific), respectively.

IgM antilymphocyte antibodies to Raji cells was not responsible for the results obtained with SLE sera, the following experiment was performed. Raji cells were incubated for $30 \mathrm{~min}$ at $37^{\circ} \mathrm{C}$ with five SLE sera, washed, and reacted with radioactive anti-IgG antibody directed against heavy and light chains (used in this study) or with radioactive anti-IgG antibody specific for IgG heavy chains. As shown in Table V, in both instances sera were equally positive for immune complexes, irrespective of the type of antiserum used. These results indicated that cold-reactive $\operatorname{IgM}$ anti-lymphocyte antibodies are not absorbed on Raji cells at $37^{\circ} \mathrm{C}$ and therefore cannot influence the results obtained with an antiserum not specific for $\operatorname{IgG}$ heavy chains.

Additional experiments with Raji cells having blocked IgG $\mathrm{Fc}$ and $\mathrm{C}$ receptors showed that no binding

TABLE VI

Raji Cell Radioimmune Assay for Immune Complexes in Patients with Vasculitis

\begin{tabular}{|c|c|c|c|c|c|}
\hline \multirow[b]{2}{*}{ Diagnosis } & \multirow{2}{*}{$\begin{array}{l}\text { No. } \\
\text { cases }\end{array}$} & \multirow{2}{*}{$\begin{array}{l}\text { No. } \\
\text { posi- } \\
\text { tive }\end{array}$} & \multirow{2}{*}{$\begin{array}{l}\text { Posi- } \\
\text { tive }\end{array}$} & \multicolumn{2}{|r|}{ AHG } \\
\hline & & & & Mean & Range \\
\hline & & & $\%$ & & $\mu g e q / m l$ \\
\hline Idiopathic vasculitis & 8 & 3 & 37.5 & 70 & $(25-102)$ \\
\hline Rheumatoid vasculitis & 7 & 5 & 71.4 & 281 & $(30-1,000)$ \\
\hline $\begin{array}{l}\text { Sjögren's syndrome } \\
\text { cryoglobulinemia- } \\
\text { vasculitis }\end{array}$ & 10 & 6 & 60 & 115 & $(75-410)$ \\
\hline
\end{tabular}

TABLE VII

Raji Cell Radioimmune Assay for Immune Complexes in Patients with $D H F$

\begin{tabular}{lccc}
\hline & \multirow{2}{*}{$\begin{array}{c}\text { No. } \\
\text { cases }\end{array}$} & $\begin{array}{c}\text { No. } \\
\text { positive }\end{array}$ & Mean $\quad$ Range \\
\hline & & & $\mu g ~ e q / m l$ \\
Grade I* & 7 & 3 & $60(24-100)$ \\
Grade II-III $\ddagger$ & 9 & 6 & $83(25-200)$ \\
Grade IV§ & 8 & 6 & $58(25-175)$ \\
\hline
\end{tabular}

* Grade I, fever, nonspecific constitutional symptoms, positive tournique test.

‡ Grade II-III, fever, skin hemorrhage, epistaxis, gum bleeding, circulatory failure, hypotension.

\& Grade IV, moribund patients, undetectable blood pressure.

of IgG at $37^{\circ} \mathrm{C}$ occurs from SLE sera containing antilymphocyte antibodies. In these experiments $2 \times$ $10^{\circ}$ Raji cells were first incubated with $300 \mu \mathrm{g}$ AHG and then with $300 \mu \mathrm{g}$ AHG that had reacted with $50 \mu \mathrm{l}$ of NHS as a C source. Thereafter the blocked Fc and $\mathrm{C}$ receptor cells were incubated $\left(37^{\circ} \mathrm{C}, 45 \mathrm{~min}\right)$ with MEM or five different SLE sera with anti-lymphocyte antibodies and then with ${ }^{105} \mathrm{I}$-rabbit antihuman IgG. No increased uptake of radiolabeled antibody was observed with blocked cells incubated with the SLE sera over that with the blocked cells incubated with MEM.

Vascular lesions by soluble antigen-antibody complexes have been produced in experimental animals (38) and deposits of $\mathrm{Ig}, \mathrm{C}$, and certain antigens (4) have been found in the arterial walls of humans with various diseases. Therefore, sera from patients with idiopathic vasculitis, rheumatoid vasculitis, and Sjögren's syndrome associated with cryoglobulinemia and vasculitis were examined for immune complexes by the Raji cell assay, and the results are presented in Table VI. Of these patients with circulating immune complexes, mean values were $70-281 \mathrm{\mu g}$ AHG eq/ml serum. There was no correlation between the amount of immune complexes present in rheumatoid vasculitis patients and the rheumatoid factor (19S) titers. Furthermore, addition of 19S rheumatoid factor to SLE sera did not interfere with the assay.

Sera from patients with DHF, a group B arthropodborne virus infection (39), were also tested for immune complexes (Table VII). Circulating immune complexes were found in all grades of the disease (39) with mean values of 58-83 $\mu \mathrm{g}$ AHG eq/ml.

Since sera from hypocomplementemic patients may not have had enough $C$ to render immune complexes detectable by $\mathrm{C}$ receptors, hypocomplementemic sera from SLE patients positive in the Raji cell assay and from patients with idiopathic vasculitis negative for immune complexes were supplemented with NHS as a $\mathrm{C}$ source. 
No enhanced binding to Raji cells of the positive sera nor conversion of the negative sera to positive occurred. As would be expected from the preceding section, addition of $\mathrm{C}$ to positive sera resulted in a moderate inhibition of the binding of immune complexes to cellular $\mathrm{C}$ receptors.

Since it has been suggested that immune complexes, possibly made up of tumor antigens and antibodies, are present in the sera of humans and animals with tumors (40-48), sera of patients with various types of malignancies were assayed with the Raji cell test (Table VIII). Approximately one third of these patients had circulating complexes, and sera from persons with lymphoid tumors generally had more complexes than persons with solid tumors. When five positive sera were fractionated in a sucrose gradient and the positions of $\mathrm{C} 3$ and IgG were analyzed, they were found to contain heavy peaks of C3 and IgG, as opposed to control NHS and sera from cancer patients who were negative for immune complexes.

\section{DISCUSSION}

Raji cells were used in a radioimmune assay for the detection of immune complexes. In this assay, uptake of radioactive anti-human $\operatorname{IgG}$ by the cells previously incubated with sera of patients with various disorders was used to identify and quantitate circulating immune complexes. The Raji cell radioimmune assay described here is based on the ability of these cells to bind human IgG much more efficiently when it is complexed with an antigen or aggregated and has fixed $\mathrm{C}$ than when it is in its monomeric form. In fact, uptake experiments showed that approximately eight times more molecules of IgG bind via $C$ receptors than via IgG Fc receptors. The enhanced binding to Raji cells of C-containing AHG or, as shown in a previous study (22) of immune complexes made in vitro, has been attributed either to the presence of more $\mathrm{C}$ receptors than IgG Fc receptors or to the higher binding affinity of $\mathrm{C}$ receptors than IgG Fc receptors for their ligand molecules. Another possibility is that complexes containing $\mathrm{C}$ have more $\mathrm{C} 3$ than complexes without $\mathrm{C}$ have IgG Fc sites, and therefore bind better to cells $(20,22)$.

We demonstrated earlier that immune complexes containing $C$ bind to Raji cells only via $C$ receptors and that these receptors are distinct from the $\mathrm{IgG}$ Fc receptors (20). Therefore, when a serum containing C-fixing complexes of the $\mathrm{IgG}$ variety is added to Raji cells, two types of IgG binding occur. One is mediated via IgG Fc receptors and binds the uncomplexed monomeric IgG, and the other is mediated via $\mathrm{C}$ receptors and binds complexed IgG with fixed $\mathrm{C}$. In the absence of immune complexes or in the presence of non-C fixing immune complexes, IgG binds to cells via IgG Fc receptors
TABLE VIII

Raji Cell Radioimmune Assay for Immune Complexes in Patients with Malignancies

\begin{tabular}{lrrr}
\hline \multicolumn{1}{c}{ Type of malignancy } & $\begin{array}{c}\text { No. } \\
\text { cases }\end{array}$ & $\begin{array}{c}\text { No. } \\
\text { positive }\end{array}$ & AHG \\
\hline Solid tumors-total & & & $\mu g$ eq $/ \mathrm{ml}$ \\
Breast & 48 & 20 & \\
Lung & 20 & 8 & 33 \\
Stomach & 7 & 2 & 26 \\
Liver & 3 & 2 & 38 \\
Colon & 2 & 0 & 0 \\
Thyroid & 6 & 3 & 48 \\
Others & 4 & 3 & 52 \\
Lymphoid tumors-total & 6 & 2 & 30 \\
Sarcoma & 49 & 20 & \\
Hodgkin's & 6 & 3 & 33 \\
Lymphoma & 4 & 2 & 76 \\
Burkitt's & 16 & 5 & 65 \\
Multiple myeloma & 20 & 10 & 145 \\
Melanoma & 3 & 0 & 0 \\
& 7 & 3 & 56 \\
\hline
\end{tabular}

only. AHG, substituted for immune complexes in vitro, possesses many of their properties $(30,31)$ and binds to the same $F c$ and $C$ receptors on cell surfaces $(20,49)$. Since much more IgG binds to Raji cells when it has been altered so it can fix $\mathrm{C}$, the presence of IgG-type immune complexes in human sera can be quantitated by measuring uptake of radioactive antihuman IgG. Our experiments showed that uptake of radioactive antibody was proportional to the amount of AHG bound to cells, which in turn was proportional to the quantity of $\mathrm{AHG}$ present in the serum. Since the uptake of radioactive antibody was proportional to the amount of AHG present in the serum, by using the graph of uptake as a standard, the amount of soluble complexes present in test sera could readily be equated to an amount of AHG after correcting for the dilution factor.

In the Raji cell radioimmune assay, to differentiate between NHS and serum containing IgG complexes, one must add radioactive antibody in excess of the amount needed to saturate the monomeric IgG bound to cells via $\mathrm{Fc}$ receptors. In our experiments with unfractionated AHG and with aggregates of defined sizes, the Raji cell radioimmune assay efficiently identified even 18-11S aggregates. However, it should be noted that when AHG or immune complexes of defined antigen-antibody composition made in vitro are used for obtaining the reference curve, the amount of small complexes present in a serum may be underestimated. That is, serum with small amounts of large immune complexes that activate and fix $\mathrm{C}$ well may result in higher binding and antibody uptake than a greater amount of small complexes that activate and fix $\mathrm{C}$ less well. Several investigators have 
shown that activation and fixation of $\mathrm{C}$ by immune complexes or AHG are directly related to their size $(7,30,31)$, and we and others have demonstrated that immune complexes made near equivalence bind best to cellular $\mathrm{C}$ receptors $(22,32)$.

In the course of $\mathrm{C}$ activation, $\mathrm{C} 3 \mathrm{~b}$ binds to immune complexes. Complex-bound $\mathrm{C} 3 \mathrm{~b}$ is thereafter cleaved by the serum enzyme $\mathrm{C} 3 \mathrm{~b}$-inactivator into $\mathrm{C} 3 \mathrm{c}$ and $\mathrm{C} 3 \mathrm{~d}$, with the $d$ portion remaining on the immune complex (50). Therefore immune complexes in whole serum may contain C3b, C3d, or both. The receptors for C3 and $\mathrm{C} 3 \mathrm{~b}$ are the same or closely associated while the C3d receptors are different $(20,33)$. Receptors for $\mathrm{C} 3-\mathrm{C} 3 \mathrm{~b}$, and receptors for $\mathrm{C} 3 \mathrm{~d}$ are both operative in the binding of immune complexes coated with $C$ (20). Therefore, the presence of excess free $\mathrm{C} 3$ may inhibit $\mathrm{C} 3 \mathrm{~b}$-bearing immune complexes from binding to cells. As shown in the present study, excess $\mathrm{C}$ inhibited binding of AHGcontaining $\mathrm{C}$ to cells. However, this inhibitory effect was never higher than $50 \%$ of the optimum uptake. This result may be explained by the fact that excess $\mathrm{C} 3$ cannot inhibit the binding of the C3d-bearing complexes. Furthermore, apart from the $\mathrm{C} 3-\mathrm{C} 3 \mathrm{~b}$ and $\mathrm{C} 3 \mathrm{~d}$ receptors, others, such as the recently described receptors for $\mathrm{Clq}$ on Raji cells (21), may participate in the binding of C-containing immune complexes.

Our results from measuring AHG in serum prompted us to apply the Raji cell radioimmune assay to the study of sera from patients with suspected immune complex diseases. The possibility that patients with serum hepatitis have immune complexes has been under special consideration. Our results from the Raji cell assay show immune complexes in the majority $(63 \%)$ of patients with acute hepatitis and $\mathrm{HB}_{\mathbf{s}}-\mathrm{Ag}$ as well as in a smaller percentage $(40 \%)$ of patients with acute hepatitis without HBs-Ag. Our results agree well with those of Nydegger et al., who used the PEG method (10). In acute hepatitis with $\mathrm{HB}_{\mathrm{s}} \mathrm{Ag}$ a correlation was found between amount of complexes present, phase of disease, and serum enzyme levels; however, there were some exceptions. The presence of immune complexes at the acute phase of serum hepatitis fits well with the findings of others showing that anticomplementary activity occurs 4-6 wk after exposure and is reversed with excess HBs-Ag or antibody. The anticomplementary effect decreases at 12-19 wk after exposure (51). Most of the chronic carriers were negative for immune complexes, and this finding is in agreement with their lack of apparent symptoms and with the absence of anticomplementary activity in their serum observed by others (52). Several reports have confirmed an association between $\mathrm{HB}_{\mathbf{s}} \mathrm{Ag}$ and polyarteritis $(53,54)$. In addition, an immune complex mechanism has been suggested as being responsible for the vasculitis and arthralgia syndrome sometimes seen as a prodrome in patients with acute viral hepatitis $(55,56)$. Finally, $\mathrm{HB}_{\mathrm{s}}-\mathrm{Ag}$, Ig, and $\mathrm{C}$ deposits have been found in the glomeruli of few patients with glomerulonephritides (57).

Sucrose density fractionation of selected positive hepatitis sera showed the presence of a heavy peak of IgG associated with $\mathrm{HB}_{\mathrm{s}}-\mathrm{Ag}$ and $\mathrm{C}$. Oldstone and associates showed that addition of antibody and $\mathrm{C}$ to polyoma virus increased its sedimentation rate (58). In several viral infections $C$ seems to bind to virus-antibody immune complexes in vivo. Evidence that virus in the serum complexes with host $\mathrm{Ig}$ and $\mathrm{C}$ comes from experiments in which specific precipitation of either Ig or $\mathrm{C}$ from the serum removes significant amounts of infectivity, although precipitation of other serum proteins, such as albumin, removes none $(59,60)$. These authors, who found that $\mathrm{C} 1$ through $\mathrm{C} 3$ bind to virusantibody complexes, postulated that some viruses concentrate in or infect certain cells bearing $\mathrm{C} 3$ receptors such as B lymphocytes, macrophages, and monocytes (58). Since Raji cells have large numbers of $C$ receptors, they may concentrate virus-antibody- $C$ complexes present in a serum. In fact, $\mathrm{HB}_{\mathbf{s}}-\mathrm{Ag}$ could be detected by immunofluorescence on the surface of Raji cells incubated with immune complex-containing hepatitis sera.

In patients with SLE, a high degree of correlation was observed between the amount of complexes detected, disease activity, presence of low $\mathrm{C}$ levels, and presence of anti-DNA antibodies. Patients with SLE form a spectrum of antibodies that reacts with native or altered autologous antigens (61). Antibodies directed against a variety of nuclear components are common in these sera $(17,34)$, and serum antibody to native DNA accompanying low circulating $\mathrm{C}$ levels is generally associated with active lupus nephritis $(17,18,35,62)$. Furthermore, deposits of DNA, Ig, and C found in the kidneys of these patients resemble those found in experimental immune complex-induced nephritis (18). However, the nature of the presumed immune complexes detected by the Raji cells in SLE sera remains to be determined.

Sera from patients with SLE may contain antilymphocyte antibodies $(36,37)$. The possibility that much of the excess IgG detected on Raji cells is not due to the immune complexes but to anti-lymphocyte antibodies that react with these cells is in part excluded for the following reasons. First, anti-lymphocyte antibodies are primarily of the cold-reactive type $(36,37)$, but sera were absorbed with Raji cells at $37^{\circ} \mathrm{C}$. Second, most antilymphocyte antibodies are of the IgM class (37). However, positive sera remained so independently of the type of radioactive antibody used, i.e., antibody directed against heavy and light chains of human IgG or antibody directed only against heavy chains of IgG. 
Third, no binding of IgG from SLE sera occurred at $37^{\circ} \mathrm{C}$ on Raji cells with blocked $\mathrm{Fc}$ and $\mathrm{C}$ receptors. Therefore, it can be concluded that if antilymphocyte antibodies are present in SLE sera, these antibodies appear to react poorly with the Raji cell membranes under our experimental conditions. In addition, one must consider the possibility that antilymphocyte antibodies may circulate as complexes with cell surface antigen(s), and Winfield et al. (63) have shown specific concentration of antilymphocyte antibodies in the serum cryoprecipitates of patients with SLE.

The majority of sera from patients with rheumatoid vasculitis were also positive for immune complexes by the Raji cell assay. Intermediate complexes of IgG-anti IgG in sera of patients with rheumatoid vasculitis have been described (64). Since these complexes in fluid phase are generally unable to fix $C(65)$, it might be assumed that this excess IgG binds to cells by Fc receptors. AHG has many Fc sites and can displace $7 \mathrm{~S}$ IgG from the IgG Fc receptors (66). In the majority of sera from patients with idiopathic vasculitis, no immune complexes were detected by the Raji cell test. It may be that in these patients, mechanisms other than immune complexes are responsible for $\mathrm{C}$ activation and damage of the vascular walls, or that immune complexes, after their formation, are rapidly removed from the circulation and deposited on the arterial walls.

Sera as well as cerebrospinal fluids from a limited number of patients with SSPE were also found to contain immune complexes by the Raji cell assay. Measles virus has been implicated in the pathogenesis of this disease (67), and SSPE sera reportedly contain blocking factors removed by anti-C3 or rheumatoid factor (68). Furthermore, IgG and C3 deposits have been noted in the vessels of patients with SSPE (69). However, whether the antigen involved in the immune complexes from these sera is indeed the measles virus remains to be determined.

Sera from patients having DHF were found to contain immune complexes; however, the presence of dengue virus antigens in the complexes was not shown. Both the classical and alternative $C$ pathways are known to be activated in these patients' sera (70). Furthermore, Sobel et al. (71), using a radiolabeled C1q deviation test, have found Clq-reactive material in these sera as well as a direct correlation between the amount of $\mathrm{C1q}$-reactive material detected and grade of the disease. In our study, patients in the II-III grade of the disease had the highest values for immune complexes. Possibly patients with IV grade of the disease (shock syndrome) contained fewer complexes than patients with II-III grade (hemorrhage, hypotension) because the complexes had deposited on the arterial walls, because large amounts of fluids were administered intravenously, or because of $\mathrm{C}$ exhaustion. Future studies of immune complexes in serial bleedings of patients with various grades of DHF may establish a relationship between their immune complexes, $\mathrm{C}$ activation, and shock.

Our finding of complexes in the sera of more than one third of unselected cancer patients fits with the suspicion that in many cancer patients, tumor antigenantibody complexes may circulate and deposit in tissues. Studies conducted by Hellström and associates (72) as well as by others (73) have shown that circulating antibody is demonstrable only when the size of the tumor is very small, i.e., in early stages of tumor growth, after surgical removal, or after a clinical remission. When tumor antigen production is thought to be sufficient to create a condition of antigen excess (large mass of tumor), circulating antibody can no longer be demonstrated (73). At this stage, however, a serum factor, which contains or is associated with IgG, blocks the cytotoxic effect of lymphocytes against tumor cells in vitro. This factor has been termed "blocking factor", and it is believed to represent tumor antigen-antibody complexes (40). Other observations further support the concept that tumor-bearing animals and humans may have tumor antigen-antibody complexes fixed in tissues or circulating in blood. Circulating complexes and deposits of virus-antiviral antibody and $\mathrm{C}$ in the renal glomeruli are present in animal models of virus-associated leukemia, lymphoma, and sarcomá $(47,48)$, as well as in mice bearing melanoma (41) and neuroblastoma tumors (43). Moreover, such deposits have occasionally been described in the glomeruli of humans with leukemia, lymphoma, Hodgkin's disease, colon carcinoma $(46,74,75)$, and African Burkitt's lymphoma (45). Studies are in progress to ascertain the temporal relationship of immune complexes detected by the Raji cell test and activity of the disease in patients with cancer.

The sensitivity of the Raji cell radioimmune assay is significantly greater than that of other tests utilizing C1q for the detection of soluble immune complexes. Whereas $\mathrm{Clq}$ precipitation in gel (7) and radiolabeled C1q-PEG precipitation (10) detect AHG at a minimum concentration of approximately $100 \mu \mathrm{g} / \mathrm{ml}$, the Raji cell assay allows the detection of $6 \mu \mathrm{g} / \mathrm{ml}$. However, a $\mathrm{C} 1 \mathrm{q}$ deviation test was developed recently, and reportedly was about as sensitive as the Raji cell assay (71). Nevertheless, the Raji cell test may be more specific for immune complexes than the tests utilizing $\mathrm{Clq}$, since $\mathrm{Clq}$ is known to react not only with immune complexes and AHG but also with non-Ig substances, such as endotoxin and DNA $(7,71)$. Physical techniques, such as analytical and sucrose gradient centrifugation, are not sufficiently sensitive for studying most 
patients with immune complex disease. Monoclonal rheumatoid factor is a relatively sensitive precipitant of immune complexes; however, it is not as successful in detecting immune complexes in patients with SLE as in those with rheumatoid arthritis (8). Microcomplement consumption assays (13), although sensitive, may give positive results with a variety of materials that can consume $\mathrm{C}$ or inhibit $\mathrm{C}$-induced red blood cell lysis, the end point of the assay. Platelet aggregation techniques (15) are plagued by unreproducible platelet preparations, and materials other than immune complexes may cause platelet aggregation. Finally, although reported as a sensitive method of detecting immune complexes in patients with SLE (12), the macrophage inhibition assay requires isolation of macrophages from guinea pigs, the presence of rheumatoid factor interferes with the assay (76), and finally, its general clinical applicability has not yet been shown.

Apart from the ability of Raji cells to detect immune complexes in vitro, it should be pointed out that these cells, which can concentrate antigen-antibody complexes on their surfaces, may provide the tool by which antigens involved in immune complex diseases will be identified and antisera against them will be raised. Antibodies isolated from the cell-bound complexes as well as antisera raised against the antigen may be of great value in screening humans with suspected immune complex disease.

\section{ACKNOWLEDGMENTS}

The authors wish to thank Drs. H. G. Kunkel and J. B. Winfield (Rockefeller University, New York); G. R. Irwin (Walter Reed Army Medical Center, Washington, D. C.) ; K. F. Austen and N. A. Soter (Harvard Medical School, Boston, Mass.) ; J. S. Johnson, M. B. A. Oldstone, and V. A. Bokisch (Scripps Clinic); T. J. Lehar and D. R. Newman (Rees-Stealy Medical Clinic, San Diego, Calif.); and G. Klein (Karolinska Institutet, Stockholm, Sweden) who provided the experimental sera as well as pertinent laboratory data. The excellent technical assistance of Ms. Maryellen Masciangelo is gratefully acknowledged. We also thank Mss. Phyllis Minick and Sally Hendrix for their excellent editorial and secretarial assistance in the preparation of the manuscript.

This is Publication No. 984 from Scripps Clinic and Research Foundation, La Jolla, Calif. This work was supported by Contract No. DADA 17-73-C-3137 from the U. S. Department of the Army, United States Public Health Service Contract NO1-AI-42505 and Grant AI-07007, and Contract No. NO1-CB-53592 from the National Cancer Institute and the Elsa U Pardee Foundation.

\section{REFERENCES}

1. Dixon, F. J., J. D. Feldman, and J. Vazquez. 1961. Experimental glomerulonephritis. The pathogenesis of a laboratory model resembling the spectrum of human glomerulonephritis. J. Exp. Med. 113: 899-919.

2. Dixon, F. J. 1973. Immune complex diseases. J. Invest. Dermatol. 59 : 413-415.
3. Wilson, C. B., and F. J. Dixon. 1974. Diagnosis of immunopathologic renal disease. Kidney Int. 5: 389-401.

4. Oldstone, M. B. A. 1975. Virus neutralization and virusinduced immune complex disease. Virus-antibody union resulting in immunoprotection or immunologic injurytwo sides of the same coin. Prog. Med. Virol. 19: 84 119.

5. Cochrane, C. G., and D. Koffler. 1973. Immune complex disease in experimental animals and man. Adv. Immunol. 16: $186-264$.

6. Koffler, D., P. H. Schur, and H. G. Kunkel. 1967. Immunological studies concerning the nephritis of systemic lupus erythematosus. J. Exp. Med. 126: 607-623.

7. Agnello, V., R. J. Winchester, and H. G. Kunkel. 1970. Precipitin reactions of the $\mathrm{Clq}$ component of complement with aggregated $\gamma$-globulin and immune complexes in gel diffusion. Immunology. 19: 909-919.

8. Winchester, R. J., H. G. Kunkel, and V. Agnello. 1971. Occurrence of $\gamma$-globulin complexes in serum and joint fluid of rheumatoid arthritis patients : use of monoclonal rheumatoid factors as reagents for their demonstration. J. Exp. Med. 134 : 286s-295s.

9. Creighton, W. D., P. H. Lambert, and P. A. Miescher. 1973. Detection of antibodies and soluble antigen-antibody complexes by precipitation with polyethylene glycol. J. Immunol. 111: 1219-1227.

10. Nydegger, U. E., P. H. Lambert, H. Gerber, and P. H. Miescher. 1974. Circulating immune complexes in the serum in systemic lupus erythematosus and in carriers of hepatitis B antigen. Quantitation by binding to radiolabeled C1q. J. Clin. Invest. 54: 297-309.

11. Heimer, R., and J. L. Abruzzo. 1972. A latex test for the detection of human IgG aggregates and IgG antiIgG antibody. Immunochemistry. 9: 921-931.

12. Onyewotu, I. I., E. J. Holborow, and G. D. Johnson. 1974. Detection and radioassay of soluble circulating immune complexes using guinea pig peritoneal exudate cells. Nat. New Biol. 248: 156-159.

13. Mowbray, J. F., A. V. Hoffbrand, E. J. Holborow, P. P. Seah, and L. Fry. 1973. Circulating immune complexes in dermatitis herpetiformis. Lancet. 1: 400-402.

14. Jewell, D. P., and I. C. M. MacLennan. 1973. Circulating immune complexes in inflammatory bowel disease. Clin. Exp. Immunol. 14: 219-226.

15. Myllylä, G. 1973. Aggregation of human blood platelets by immune complexes in the sedimentation pattern test. Scand. J. Haematol. Suppl. 19: 1-55.

16. Brouet, J. C., J. P. Clauvel, F. Danon, M. Klein, and M. Seligmann. 1974. Biologic and clinical significance of cryoglobulinemias. Am. J. Med. 57: 775-788.

17. Koffler, D., R. Carr, V. Agnello, R. Thoburn, and H. G. Kunkel. 1971. Antibodies to polynucleotides in human sera: antigenic specificity and relation to disease. $J$. Exp. Med. 134: 294-312.

18. Koffler, D., V. Agnello, R. Thoburn, and H. G. Kunkel. 1971. Systemic lupus erythematosus: prototype of immune complex nephritis in man. J. Exp. Med. 134:169s$179 \mathrm{~s}$.

19. Franklin, E. C., H. R. Holman, H. J. Müller-Eberhard, and H. G. Kunkel. 1957. An unusual protein component of high molecular weight in the serum of certain patients with rheumatoid arthritis. J. Exp. Med. 105: 425438.

20. Theofilopoulos, A. N., F. J. Dixon, and V. A. Bokisch. 1974. Binding of soluble immune complexes to human lymphoblastoid cells. I. Characterization of receptors 
for IgG Fc and complement and description of the binding mechanism. J. Exp. Med. 140: 877-894.

21. Sobel, A. T., and V. A. Bokisch. 1975. Receptor for C1q on peripheral human lymphocytes and human lymphoblastoid cells. Fed. Proc. 34: 965.

22. Theofilopoulos, A. N., C. B. Wilson, V. A. Bokisch, and F. J. Dixon. 1974. Binding of soluble immune complexes to human lymphoblastoid cells. II. Use of Raji cells to detect circulating immune complexes in animal and human sera. J. Exp. Med. 140: 1230-1244.

23. Pulvertaft, R. J. V. 1965. A study of malignant tumors in Nigeria by short-term tissue culture. J. Clin. Pathol. 18 : $261-273$.

24. Ferrari, A. 1960. Nitrogen determination by a continuous digestion and analysis system. Ann. N. Y. Acad. Sci. 87: 792-800.

25. Bokisch, V. A., H. J. Müller-Eberhard, and C. G. Cochrane. 1969. Isolation of a fragment (C3a) of the third component of human complement containing anaphylatoxin and chemotactic activity and description of an anaphylatoxin inactivator of human serum. J. Exp. Med. 129: 1109-1130.

26. Clark, H. F., and C. C. Shepard. 1963. A dialysis technique for preparing fluorescent antibody. Virology. 20: 642-644.

27. McConahey, P. J., and F. J. Dixon. 1966. A method of trace iodination of proteins for immunologic studies. Int. Arch. Allergy Appl. Immunol. 29: 185-189.

28. Mancini, G., A. O. Carbonara, and J. F. Heremans. 1965. Immunochemical quantitation of antigens by single radial immunodiffusion. Immunochemistry. 2: 235-254.

29. Gocke, D. J., and C. Howe. 1970. Rapid detection of Australia antigen by counterimmunoelectrophoresis. $J$. Immunol. 104 : 1031-1032.

30. Ishizaka, K., T. Ishizaka, and J. Banovita. 1965. Biological activities of aggregated $\gamma$-globulin. VII. Minimum size of aggregated $\boldsymbol{\gamma}$-globulin or its piece III required for the induction of skin reactivity and complement fixation. J. Immunol. 94: 824-832.

31. Christian, C. L. 1960. Studies of aggregated $\gamma$-globulin. I. Sedimentation, electrophoretic and anticomplementary properties. J. Immunol. 84: 112-116.

32. Eden, A., C. Bianco, and V. Nussenzweig. 1973. Mechanism of binding of soluble immune complexes to lymphocytes. Cell. Immunol. 7: 459-473.

33. Theofilopoulos, A. N., V. A. Bokisch, and F. J. Dixon. 1974. Receptor for soluble C3 and C3b on human lymphoblastoid (Raji) cells. Properties and biological significance. J. Exp. Med. 139: 696-711.

34. Friou, G. J. 1967. Antinuclear antibodies. Diagnostic significance and methods. Arthritis Rheum. 10: 151-159.

35. Tan, E. M., P. H. Schur, R. I. Carr, and H. G. Kunkel. 1966. Deoxyribonucleic acid (DNA) and antibodies to DNA in the serum of patients with systemic lupus erythematosus. J. Clin. Invest. 45: 1732-1740.

36. Winchester, R. J., J. B. Winfield, F. Siegal, P. Wernet, Z. Bentwich, and H. G. Kunkel. 1974. Analyses of lymphocytes from patients with rheumatoid arthritis and systemic lupus erythematosus; occurrence of interfering cold-reactive anti-lymphocyte antibodies. J. Clin. Invest. 54 : 1082-1092.

37. Winfield, J. B., R. J. Winchester, P. Wernet, S. M. Fu, and H. G. Kunkel. 1975. Nature of cold reactive antibodies to lymphocyte surface determinants in systemic lupus erythematosus. Arthritis Rheum. 18: 1-8.

38. Dixon F. J., and C. G. Cochrane. 1970. The patho- genicity of antigen-antibody complexes. Pathol. Annu. 5: 335-379.

39. Bokisch, V. A. 1974. The role of complement in hemorrhagic shock syndrome (dengue). In Progress in Immunology. Vol. II. L. Brent and J. Holborow, editors. North-Holland Publishing Company, Amsterdam. 4: 151-159.

40. Sjögren, H. O., I. Hellström, S. C. Bansal, and K. E. Hellström. 1971. Suggestive evidence that the "blocking antibodies" of tumor-bearing individuals may be antigen-antibody complexes. Proc. Natl. Acad. Sci. U.S. A. 68: $1372-1375$.

41. Poskitt, P. K. F., T. R. Poskitt, and J. H. Wallace. 1974. Renal deposition of soluble immune complexes in mice bearing B-16 melanoma. Characterization of complexes and relationship to tumor progress. J. Exp. Med. $140: 410-425$

42. Baldwin, R. W., M. R. Price, and R. A. Robins. 1972. Blocking of lymphocyte-mediated cytotoxicity for rat hepatoma cells by tumor-specific antigen-antibody complexes. Nat. New Biol. 238: 185-187.

43. Oldstone, M. B. A. 1975. Immune complexes in cancer. Demonstration of complexes in mice bearing neuroblastoma. J. Natl. Cancer Inst. 54: 223-226.

44. Ludwig, F. J., and C. L. Cusumano. Detection of immune complexes using ${ }^{125}$ I goat anti (human IgG) monovalent $\left(\mathrm{Fab}^{\prime}\right)$ antibody fragments. J. Natl. Cancer Inst. 52: $1529-1536$

45. Oldstone, M. B. A., A. N. Theofilopoulos, G. Klein, and P. Gunven. 1975. Immune complexes associated with neoplasia: Presence of Epstein-Barr virus antigen-antibody complexes in Burkitt's lymphoma. Intervirology. 4: 292-302.

46. Constanza, M. E., V. Pinn, R. S. Schwartz, and L. Nathanson. 1973. Carcinoembryonic antigen-antibody complexes in a patient with colonic carcinoma and nephrotic syndrome. N. Engl. J. Med. 289: 520-523.

47. Yoshiki, T., R. C. Mellors, M. Strand, and J. T. August. 1974. The viral envelope glycoprotein of murine leukemia virus and the pathogenesis of immune complex glomerulonephritis of New Zealand mice. J. Exp. Med. 140 : $1011-1027$.

48. Oldstone, M. B. A., A. Tishon, G. Tonietti, and F. J. Dixon. 1972. Immune complex disease associated with spontaneous murine leukemia: Incidence and pathogenesis of glomerulonephritis. Clin. Immunol. Immunopath. $1: 6-14$.

49. Dickler, H. B. 1974. Studies of the human lymphocyte receptor for heat-aggregated or antigen-complexed immunoglobulin. J. Exp. Med. 140: 508-522.

50. Ruddy, S., and K. F. Austin. 1971. C3b inactivator of man. II. Fragments produced by $\mathrm{C} 3 \mathrm{~b}$ inactivator cleavage of cell-bound or fluid phase C3b. J. Immunol. 107: 742-750.

51. Shulman, N. R., and L. F. Barker. 1969. Virus-like antigen, antibody and antigen-antibody complexes in hepatitis measured by complement fixation. Science (Wash. D. C.). 165: 304-306.

52. Simons, M. J. 1974. Hepatitis B (Australia) antigen. In Progress in Immunology II, vol. 4. L. Brent and J. Holborow, editors. North-Holland Publishing Company, Amsterdam. 326-330.

53. Gocke, D. J., K. Hsu, C. Morgan, S. Bombardieri, M. Lockshin, and C. L. Christian. 1970. Association between polyarteritis and Australia antigen. Lancet. 2: 1149-1153.

54. Trepo, C. G., A. J. Zuckerman, R. C. Bird, and A. M. 
Prince. 1974. The role of circulating hepatitis B antigen/antibody immune complexes in the pathogenesis of vascular and hepatic manifestations in polyarteritis nodosa. J. Clin. Pathol. 27: 863-868.

55. Gocke, D. J., K. Hsu, C. Morgan, S. Bombardieri, M. Lockshin, and C. L. Christian. 1971. Vasculitis in association with Australia antigen. J. Exp. Med. 134: 330s$336 s$.

56. Wands, J. R., E. Mann, E. Alpert, and K. J. Isselbacher. 1975. The pathogenesis of arthritis associated with acute hepatitis-B surface antigen-positive hepatitis. Complement activation and characterization of circulating immune complexes. J. Clin. Invest. 55: 930-936.

57. Kohler, P. F., R. E. Cronin, W. S. Hammond, D. Olin, and R. I. Carr. 1974. Chronic membranous glomerulonephritis caused by hepatitis B antigen-antibody immune complexes. Ann. Intern. Med. 81: 448-451.

58. Oldstone, M. B. A., N. R. Cooper, and D. L. Larson. 1974. Formation and biologic role of polyoma virusantibody complexes. A critical role for complement. J. Exp. Mcd. 140 : 549-564.

59. Notkins, A. L., S. Mahar, C. Scheele, and J. Goffman. 1966. Infectious virus-antibody complex in the blood of chronically infected mice. J. Exp. Med. 124: 81-97.

60. Oldstone, M. B. A., and F. J. Dixon. 1969. Pathogenesis of chronic disease associated with persistent lymphocytic choriomeningitis viral infection. I. Relationship of antibody production to disease in neonatally infected mice. J. Exp. Med. 129: 483-505.

61. Kunkel, H. G., and E. M. Tan. 1964. Autoantibodies and disease. Adv. Immunol. 4 : 351-395.

62. Robitaille, P., and E. M. Tan. 1973. Relationship between deoxyribonucleoprotein and deoxyribonucleic acid antibodies in systemic lupus erythematosus. J. Clin. Inzest. 52 : 316-322.

63. Winfield, J. B., R. J. Winchester, P. Wernet, and H. G. Kunkel. 1975. Specific concentration of antilymphocyte antibodies in the serum cryoprecipitates of patients with systemic lupus erythematosus. Clin. Exp. Immunol. 19: 399-406.

64. Theofilopoulos, A. N., G. Burtonboy, J. J. LoSpalluto, and M. Ziff. 1974. IgG rheumatoid factor and low molecular weight IgM in rheumatoid arthritis: An association with vasculitis. Arthritis Rheum. 17: 272-283.

65. Pope, R. M., D. C. Teller, and M. Mannik. 1975. Intermediate complexes formed by self-association of IgGrheumatoid factors. Ann. N. Y. Acad. Sci. 1256: 82-87.
66. Dickler, H. B., and H. G. Kunkel. 1972. Interaction of aggregated $\gamma$-globulin with B lymphocytes. J. Exp. Med. 136: 191-196.

67. Sever, J. L., and W. Zeman, editors. 1968. Conference on "Measles Virus and Subacute Sclerosing Panencephalitis". Neurology. 18(Part 2) : 1-7.

68. Ahmed, A., D. M. Strong, K. W. Sell, G. B. Thurman, R. C. Knudsen, R. Wistar, Jr., and W. R. Grace. 1974. Demonstration of a blocking factor in the plasma and spinal fluid of patients with subacute sclerosing panencephalitis. I. Partial characterization. J. Exp. Med. 139: 902-924.

69. Whitaker, J. W., and W. K. Engel. 1972. Vascular deposits of immunoglobulin and complement in idiopathic inflammatory myopathy. N. Engl. J. Med. 286: 333-338.

70. Bokisch, V. A., F. H. Top, Jr., P. K. Russell, F. J. Dixon, and H. J. Müller-Eberhard. 1973. The potential pathogenic role of complement in dengue hemorrhagic shock syndrome. N. Engl. J. Med. 289: 996-1000.

71. Sobel, A. T., V. A. Bokisch, and H. J. Müller-Eberhard. 1975. Clq deviation test for the detection of immune complexes, aggregates of IgG, and bacterial products in human serum. J. Exp. Med. 142: 139-151.

72. Hellström, I., K. E. Hellström, H. O. Sjögren, and G. A. Warner. 1971. Serum factors in tumor-free patients canceling the blocking of cell-mediated tumor immunity. Int. J. Cancer. 8: 185-191.

73. Ambrose, K., N. G. Anderson, and J. H. Coggin. 1971. Cytostatic antibody and SV-40 tumor immunity in hamsters. Nature (Lond.). 233: 321-324.

74. Sutherland, J. C., and M. R. Mardiney, Jr. 1973. Immune complex disease in the kidneys of lymphomaleukemia patients: the presence of an oncornavirusrelated antigen. J. Natl. Cancer Inst. 50: 633-639.

75. Sutherland, J. C., R. V. Markham, Jr., H. E. Ramsey, and M. R. Mardiney, Jr. Subclinical immune complex nephritis in patients with Hodgkin's disease. Cancer Res. 34 : 1179-1181.

76. Onyewotu, I. I., P. M. Johnson, G. D. Johnson, and E. J. Holbrow. 1975. Enhanced uptake by guinea pig macrophages of radio-iodinated human aggregated immunoglobulin $G$ in the presence of sera from rheumatoid patients with cutaneous vasculitis. Clin. Exp. Immunol. 19: $267-280$. 